\title{
Genetic Control and Location of QTLs Involved in Antioxidant Capacity and Fruit Quality Traits in Peach [Prunus persica (L.) Batsch]
}

\author{
W. Abidi*, C. M. Cantín, T. Buhner, M.J. Gonzalo, M.A. Moreno and Y. Gogorcena \\ Estación Experimental de Aula Dei (CSIC), Dpto. Pomología. Apdo. 13034, 50080 Zaragoza, Spain
}

Keywords: Prunus persica, total phenolics, L-ascorbic acid, flavonoids, anthocyanins, antioxidant capacity

\begin{abstract}
In peach fruits, phenolic compounds serve as a major source of potential antioxidants which are known to play a significant role in fruit quality and in human wellbeing. This study was conducted in a F1 population derived from the cross 'Venus' $x$ 'Big Top' nectarines in order to investigate the variability in the fruit antioxidant content and to study the genetic control and location of QTLs involved in fruit quality traits. Biochemical analyses have been performed to measure Lascorbic acid (vitamin $\mathrm{C}$ ), total phenolics, flavonoids, anthocyanins contents and antioxidant capacity.
\end{abstract}

\section{INTRODUCTION}

Peach and nectarine fruit [Prunus persica (L.) Batch] are the second most important fruit crop in the European Union (EU) after apples (Iglesias and Echeverría, 2008). Peach, a member of the Prunoideae subfamily, is one of the most widely grown and the best genetically characterized species in the Rosaceae family, it is a self-fertile and naturally self-pollinating fruit species with very low genetic variability (Scorza et al., 1985). As a result of its small genome size, the developing genomic resources, and the colinearity of the peach genome within Prunus, diploid peach has become a model genome for these fruit crops, providing a platform for comparative studies within the entire Rosaceae (Abbott et al., 2002).

Peach fruit contain ascorbic acid (vitamin C), carotenoids (provitamin A), and phenolic compounds that are good sources of antioxidants (Byrne, 2002). Phenolic compounds represent the major sources of antioxidant capacity in peaches (Cantin et al., 2009; Chang et al., 2000); although vitamin C also contributes to antioxidant capacity (Gil et al., 2002). These naturally occurring substances not only have a role in the visual appearance (pigmentation and browning) and taste (astringency) of fruit, but also have health-promoting properties, acting as antioxidants by scavenging harmful free radicals which are implicated in most degenerative diseases (Rice-Evans et al., 1996; Cantín et al., 2009). These benefits make phenolic compounds an interesting target for breeding programmes.

The development of molecular markers and linkage maps provides efficient tools to locate genes or quantitative trait loci (QTLs) involved in agronomical characters and could be helpful for monitoring of breeding programs (Young, 1996). QTLs for traits, which determine fruit quality in peach, have been localized on maps (Dirlewanger et al., 1998). Most of the QTLs affecting fruit quality characters have been localized in few linkage groups. In linkage group 6, QTLs associated with sucrose, sorbitol, soluble solid content, malic acid and citric acid have been identified (Dirlewanger et al., 1999; Etienne et al., 2002). 
The purpose of the present research was to measure the variation of major antioxidant compounds in peach fruits of a total of 75 genotypes derived from the cross 'Venus' x 'Big Top' nectarines, to evaluate the antioxidant capacity and to search for QTLs involved in these fruit quality traits.

\section{MATERIALS AND METHODS}

\section{Plant Material}

The progeny assayed was a segregant F1 population of 75 seedlings obtained from a controlled cross made in 2000-2001, between P. persica cvs. 'Venus' (female parent) and 'BigTop' (male parent), in collaboration with Agromillora Catalana S.A. 'Venus' is a FMF (freestone melting flesh) nectarine cultivar, whereas 'BigTop' is a CMF (clingstone melting flesh) nectarine cultivar. The segregant population is entirely melting flesh, either cling- or freestone. Progenies were established during 2001 in a plot at the Experimental Station of Aula Dei (Zaragoza, Spain).

\section{DNA Extraction and Molecular Analysis}

DNA was extracted from leaves of 'Venus', 'Big Top' and all the progeny (75 genotypes) by using the DNeasy Plant Mini Kit (QIAGEN Inc., Valencia, CA), following manufactured instructions. For initial polymorphism testing in LG 6, eleven markers were used (Table 1) and assays were performed on 'Venus', 'Big Top', and six progenies. For the PCR reactions, $10 \mathrm{ng}$ of genomic DNA was amplified in a final volume of $15 \mu \mathrm{l}$ containing $1 \mathrm{X}$ biotools buffer, $2.0 \mathrm{mM} \mathrm{MgCl} 2,0.20 \mathrm{mM}$ of dNTPs, $0.15 \mu \mathrm{M}$ of each primer pair and $0.5 \mathrm{U}$ Taq DNA polymerase (Biotools, Madrid, Spain). The PCR conditions were as follows: preliminary denaturation $\left(3 \mathrm{~min}\right.$ at $94{ }^{\circ} \mathrm{C}$ ), followed by 35 cycles consisting of denaturation $\left(1 \mathrm{~min}\right.$ at $\left.94{ }^{\circ} \mathrm{C}\right), 45 \mathrm{~s}$ at the corresponding annealing temperature and extension $\left(1 \mathrm{~min}\right.$ at $\left.72^{\circ} \mathrm{C}\right)$, and a final extension after the last cycle $(7$ $\min$ at $72{ }^{\circ} \mathrm{C}$ ).

\section{Biochemical Analyses}

Five representative fruits were selected at harvest. They were peeled, cut in pieces, and $5 \mathrm{~g}$ samples were prepared, which were frozen in liquid nitrogen and stored at $-20^{\circ} \mathrm{C}$ until analyses. Fruit samples were analyzed for vitamin $\mathrm{C}$, total phenolics, flavonoids and anthocyanins content, and antioxidant capacity as described by Cantín et al. (2009). For the determination of ascorbic acid the samples were kept frozen in 5\% metaphosphoric acid and homogenized at $4{ }^{\circ} \mathrm{C}$. Then, they were centrifuged at $16,000 \mathrm{~g}$ for 20 min at $4{ }^{\circ} \mathrm{C}$, and the supernatant was immediately used for vitamin $\mathrm{C}$ analysis. Absorbance was measured at $525 \mathrm{~nm}$ and the amount of vitamin $\mathrm{C}$ was expressed as $\mathrm{mg}$ of ascorbic acid (AsA) per $100 \mathrm{~g}$ fresh weight (FW) (Zaharieva and Abadía, 2003).

\section{Mapping and QTL analysis}

Polymorphic microsatellite markers were used to construct a partial map of the linkage group 6 with JoinMap 4.0 software (Van Ooijen, 2006). QTL analysis was implemented with MapQTL 5.0 (Van Ooijen, 2004) by interval mapping.

\section{RESULTS AND DISCUSSION}

The results obtained for all biochemical traits studied showed a normal distribution typical of quantitative characters (Fig. 1). Considerable differences were 
found in the content of all antioxidant compounds in the parents of the population, 'Venus' and 'Big Top' (Table 2).

\section{Vitamin C}

Average ascorbic acid content ranged from 1.3 to $9.5 \mathrm{mg}$ of AsA/100g of FW with a mean value of $3.9 \mathrm{mg}$ of AsA/100 g FW (Table 2) and it showed high variation between genotypes (Fig. 1). Values were in the same range as previously reported for vitamin $\mathrm{C}$ contents in peach flesh, namely, 1-14 mg of AsA/100 g of FW (Tavarini et al., 2008). Cantín et al. (2009) reported that the total ascorbic acid (vitamin C) content greatly varied from approximately 1 to $9 \mathrm{mg}$ of AsA/100 g of FW, with a mean value of $3.7 \mathrm{mg}$ of AsA/100 g of FW in several peach genotypes. Gil et al. (2002) reported that the total ascorbic acid contents (mg/100 g FW) of nectarine and peach cultivars from California, were from 6 to 8 in yellow-flesh nectarines and from 5 to 14 in white-flesh nectarines. This variation is justified by many pre- and postharvest factors which influence the vitamin $\mathrm{C}$ content of horticultural crops. Maturity at harvest, harvesting method, and postharvest handling conditions also affect the vitamin $\mathrm{C}$ content of fruits and vegetable (Kader, 1988). It is also been reported that the production of vitamin $\mathrm{C}$ increases at ripening stage to balance a decrease in polyphenol concentration in order to protect fruits against damages and oxidation.

\section{Phenolic Compounds}

Total phenolics ranged from 23 to $51 \mathrm{mg} \mathrm{GAE} / 100 \mathrm{~g}$ of FW (Table 2), and showed less variation between genotypes. The amounts of total phenolics fell within the range reported in the literature for peach fruits, namely 14-77 mg GA/100 g of FW (Proteggente et al., 2002). Cantín et al. (2009) reported that total phenolics varied among genotypes with values in the range of 12.7-71.3 $\mathrm{mg}$ of GAE/100 $\mathrm{g}$ of FW. Gil et al. (2002) reported that total phenolics (in mg CGA /100 g of FW) were 14-102 in white-flesh nectarines and 18-54 in yellow-flesh nectarines. Marinova et al. (2005), characterizing the content of total phenolics in fruit reported that in peaches the values were $50.9 \mathrm{mg}$ GAE/100g of FW. Tavarini et al. (2008) reported that the content of phenols ranged between 14 and 50 $\mathrm{mg} \mathrm{GA} / 100 \mathrm{~g}$ of FW.

Flavonoids ranged from 5 to $47 \mathrm{mg} \mathrm{CE} / 100 \mathrm{~g}$ of FW (Table 2) with an average of $21 \mathrm{mg}$ of CE/100 $\mathrm{g}$ of FW. Cantín et al. (2009) reported that total flavonoids content ranged from 1.8 to $30.9 \mathrm{mg}$ of CE/100 $\mathrm{g}$ of $\mathrm{FW}$, with an average of $8.8 \mathrm{mg}$ of CE / $100 \mathrm{~g}$ of FW. Marinova et al (2005), characterizing the content of flavonoids in fruit reported that in peaches the values were $15.0 \mathrm{mg} \mathrm{CE} / 100 \mathrm{~g}$ of $\mathrm{FW}$. The anthocyanins content showed a normal distribution and ranged from 0.3 to $5 \mathrm{mg} \mathrm{C} 3 \mathrm{G} \mathrm{eq} / \mathrm{kg}$ of $\mathrm{FW}$ (Table 2), but presented less variation between genotypes as compared to ascorbic acid. Cantín et al (2009) reported that total anthocyanins greatly varied among genotypes [0.1-26.7 $\mathrm{mg}$ of cyanidin-3-glucoside equivalents (C3GE) per $\mathrm{kg}$ of $\mathrm{FW}$ ] depending on the red pigmentation of the flesh. Lavelli et al. (2009) reported that the cyanidin 3-O-glucoside in peach samples ranged from 0 to $9.4 \mathrm{mg} / \mathrm{kg}$.

Antioxidant capacity (RAC) ranged from 255 to 1099 ( $\mu$ g Trolox/g of FW) (Table 2). Cantín et al. (2009) reported that the relative antiradical capacity (RAC) varied among genotypes, with values ranging from 227.3 to $629.9 \mu \mathrm{g}$ of Trolox/g of FW, with an average of $405 \mu \mathrm{g}$ of Trolox/g of FW. Cevallos-Casals et al (2002) reported that the redfleshed peaches had lower levels of antioxidant activity (440 to $1784 \mu \mathrm{g}$ equivalent Trolox/ $\mathrm{g}$ of tissue). The antioxidant content in peaches varied greatly depending on the 
type of the fruit (melting, non melting and nectarine), cultivar, genetic and environmental factors. Furthermore, as it happens for other climacteric fruits that are often picked before the full ripe stage, peach antioxidant content may be affected by the ripening stage at harvest. The antioxidant capacity of fruits varies in relation to the antioxidant molecules present in the different species (Wang et al., 1996) but variations can also occur within the genotype of a single species (Gil et al., 2002).

\section{Mapping and QTL Analysis}

For QTLs detection, the partial map of the linkage group 6 was constructed containing six polymorphic SSR markers (Fig. 2). However, significant QTLs have not been identified until now for the control of the biochemical traits analyzed.

\section{CONCLUSIONS}

In the current study, the variability in the fruit antioxidant content in the 'Venus' $\mathrm{x}$ 'Big Top' progeny are presented. All the traits analyzed showed a normal distribution and a high variability between genotypes. QTLs involved in the control of biochemical traits and antioxidant capacity were not localized in LG6. The addition of new polymorphic markers to this linkage group is being implemented to complete the map in order to find significant QTLs affecting these traits.

\section{ACKNOWLEDGEMENTS}

We thank R. Giménez, E. Sierra and J. Aparicio for technical assistance. This study was funded by the Spanish MICINN (Ministry of Science and Innovation) grant AGL-2008-00283, cofunded by FEDER, and the Regional Government of Aragon (A44). W. Abidi was supported by a JAE fellowship from CSIC (Consejo Superior de Investigaciones Científicas).

\section{Literature Cited}

Abbott, AG., Georgi, L., Inigo, M., Sosinski, B., Yvergniaux, D., Wang, Y., Blenda, A and Reighard, G. 2002. Peach: the model genome for Rosaceae. Acta Hort. 575:145-155.

Byrne, D.H. 2002. Peach breeding trends. Acta Hort. 592:49-59.

Cantín, C., Moreno, M.A and Gogorcena, Y. 2009. Evaluation of the antioxidant capacity, phenolic compounds, and vitamin $\mathrm{C}$ content of different peach and nectarine [Prunus persica (L.) Batsch] breeding progenies. J. Agric. Food Chem. 57:45864592.

Cevallos-Casals, B.A., Byrne, D.H. and Cisneros-Zevallos, L. 2002. Total phenolic and anthocyanin content in red-fleshed peaches and plums. Acta Hort. 592:589-592.

Chang, S., Tan, C., Frankel, E.L and Barrett, D.M. 2000. Low-density lipoprotein antioxidant activity of phenolic compounds and polyphenol oxidase activity in selected clingstone peach cultivars. J. Agric. Food Chem. 48:147-151.

Dirlewanger, E., Pronier, V., Parvery, C., Rothan, C., Gye, A. and Monet, R. 1998. Genetic linkage map of peach (Prunus persica (L.) Batsch) using morphological and molecular markers. Theor. Appl. Genet. 97:888-895.

Dirlewanger, E., Moing, A,, Rothan, C., Svanella, L., Pronier, V., Gye, A., Plomion, C., Monet, R. 1999. Mapping QTLs controlling fruit quality in peach (Prunus persica (L.) Batsch). Theor. Appl. Genet. 98:18-31. 
Etienne, C., Rothan, C., Moing, A., Plomion, C., Bodénès, C., Svanella-Dumas, L., Cosson, P., Pronier, V., Monet, R and Dirlewanger, E. 2002. Candidate genes and QTLs for sugar and organic acid content in peach [Prunus persica (L.) Batsch]. Theor. Appl. Genet.105:145-159.

Gil, M., Tomas-Barberán, A. T., Hess-Pierce, B and Kader, A. A. 2002. Antioxidant capacities, phenolic compounds, carotenoids and vitamin $\mathrm{C}$ content of nectarine and plum cultivars from California. J. Agric. Food Chem. 50:4976-4982.

Iglesias, I. and Echeverria, G., 2008. Differential effect of cultivar and harvest date on nectarine colour, quality and consumer acceptance I. Acta Hort. 120:41-50.

Kader, A.A., 1988. Influence of preharvest and postharvest environment on nutritional composition of fruits and vegetables. In: Quebedeaux, B., Bliss, F.A. (Eds.), Horticulture and Human Health: Contributions of Fruits and Vegetables. Proceedings of the $1^{\text {st }}$ International Symposium on Horticulture and Human Health. Prentice-Hall, Englewood Cliffs, NJ, pp. 18-32.

Lavelli, V., Pompei, C and Casadei, M.A. 2009. Quality of nectarine and peach nectars as affected by lye-peeling and storage. J. Agric. Food Chem. 115:1291-1298.

Marinova, D.; Ribarova, F. and Atanassova, M. 2005. Total phenolics and total flavonoids in bulgarian fruits and vegetables. J. Chem. Tech. Meta., 40, 3:255260.

Ogundiwin, E.A., Peace, C.P., Gradziel, T.M., Parfitt, D.E., Bliss, F.A. and Crisosto, C.H. 2009. A fruit quality gene map of Prunus. BMC Genomics (submitted).

Proteggente, A.R., Pannala, A.S and Paganga, 2002. The antioxidant activity of regularly consumed fruit and vegetables reflects their phenolics and vitamin $\mathrm{C}$ composition. Free Radical Res. 36:217-233.

Rice-Evans, C., Miller, N and Paganga, G. 1996. Structure-antioxidant activity relationships of flavonoids and phenolic acids. Free Radical Biol. Med. 20:933956.

Scorza, R., Mehlenbacher, SA and Lightner, GW. 1985. Inbreeding and co-ancestry of freestone peach cultivars of the eastern United States and implications for peach germplasm improvement. Acta Hort. 110:547-552

Tavarini, S., Degl'Innocenti, E., Remorini, D., Massai, R and Guidi, L. 2008. Preliminary characterisation of peach cultivars for their antioxidant capacity. J. Food Sci.Tech. 43:810-815.

Van Ooijen, J.W. 2004. MapQTL 5, Software for the mapping of quantitative trait loci in experimental populations of diploids species. Kyazma B.V., Wageningen, Netherlands.

Van Ooijen, J.W. 2006. JoinMap 4, Software for the calculation of genetic linkage maps in experimental populations. Kyazma B.V., Wageningen, Netherlands.

Wang, H., Cao, G. H and Prior, R. L. 1996. Total antioxidant capacity of fruits. J. Agric. Food Chem. 44:701-705.

Zaharieva, T. and Abadía, J. 2003. Iron deficiency enhances the levels of ascorbate, glutathione and related enzymes in sugar beet roots. Protoplasma, 221:269-275. 
Table 1. SSR markers tested for polymorphism in the progeny

\begin{tabular}{lcccc}
\hline Locus code & Reference & Polymorphism & $\begin{array}{c}\text { Tra } \\
\text { Annealing } \\
\left({ }^{\circ} \mathbf{C}\right)\end{array}$ & $\begin{array}{c}\text { Size range } \\
\text { (bp) }\end{array}$ \\
\hline pchcms5 & Abbott et al., 2000 & polymorphic & $52^{\circ} \mathrm{C}$ & $240-260$ \\
BPPCT025 & Dirlewanger et al., 2002 & polymorphic & $57^{\circ} \mathrm{C}$ & $155-175$ \\
CPPCT030 & Aranzana et al., 2002 & polymorphic & $52^{\circ} \mathrm{C}$ & $170-200$ \\
BPPCT008 & Dirlewanger et al., 2002 & monomorphic & $59^{\circ} \mathrm{C}$ & $140-160$ \\
UDP98-407 & Testolin et al., 2000 & polymorphic & $60^{\circ} \mathrm{C}$ & $180-190$ \\
UDP98-412 & Testolin et al., 2000 & polymorphic & $57^{\circ} \mathrm{C}$ & $95-140$ \\
UDP98-416 & Testolin et al., 2000 & monomorphic & $57^{\circ} \mathrm{C}$ & $80-90$ \\
UDP96-001 & Testolin et al., 2000 & monomorphic & $57^{\circ} \mathrm{C}$ & 120 \\
UDP96-010 & Testolin et al., 2000 & monomorphic & $57^{\circ} \mathrm{C}$ & 131 \\
Chill1 & Ogundiwin et al., in press & polymorphic & $60^{\circ} \mathrm{C}$ & - \\
Chill2 & Ogundiwin et al., in press & polymorphic & $60^{\circ} \mathrm{C}$ & - \\
\hline
\end{tabular}

Table 2. Variation of the amounts of antioxidants compounds in the studied progeny and the parents.

\begin{tabular}{lccccc}
\hline & \multicolumn{2}{c}{ Progenitors } & \multicolumn{3}{c}{ Progeny } \\
\hline Traits & 'Venus' & 'Big Top' & Min & Max & Means \pm SD \\
\hline $\begin{array}{l}\text { Vitamin C } \\
\text { (mg As A /100 g of FW) }\end{array}$ & 3.3 & 5.6 & 1.3 & 9.5 & $3.9 \pm 1.7$ \\
$\begin{array}{l}\text { Total phenolics } \\
\text { (mg GAE/100 g of FW) }\end{array}$ & 36.5 & 46.6 & 23.0 & 51.2 & $44.0 \pm 6.1$ \\
$\begin{array}{l}\text { Flavonoids } \\
\text { (mg CE/100g of FW) }\end{array}$ & 13.7 & 16.9 & 5.0 & 47.0 & $21.2 \pm 9.4$ \\
$\begin{array}{l}\text { Anthocyanins } \\
\text { (mg C3G eq /kg of FW) }\end{array}$ & 1.9 & 1.4 & 0.3 & 5.0 & $1.7 \pm 0.7$ \\
$\begin{array}{l}\text { Antioxidant Capacity } \\
(\mu g \text { Trolox/g of FW) }\end{array}$ & 423.0 & 926.2 & 255.0 & 1099.5 & $617.0 \pm 200$ \\
$\begin{array}{l}\text { AsA= Ascorbic acid; C3G eq = Cyanidin-3-glucoside equivalents; CE= catechin equivalents; GAE= gallic } \\
\text { acid equivalents }\end{array}$
\end{tabular}




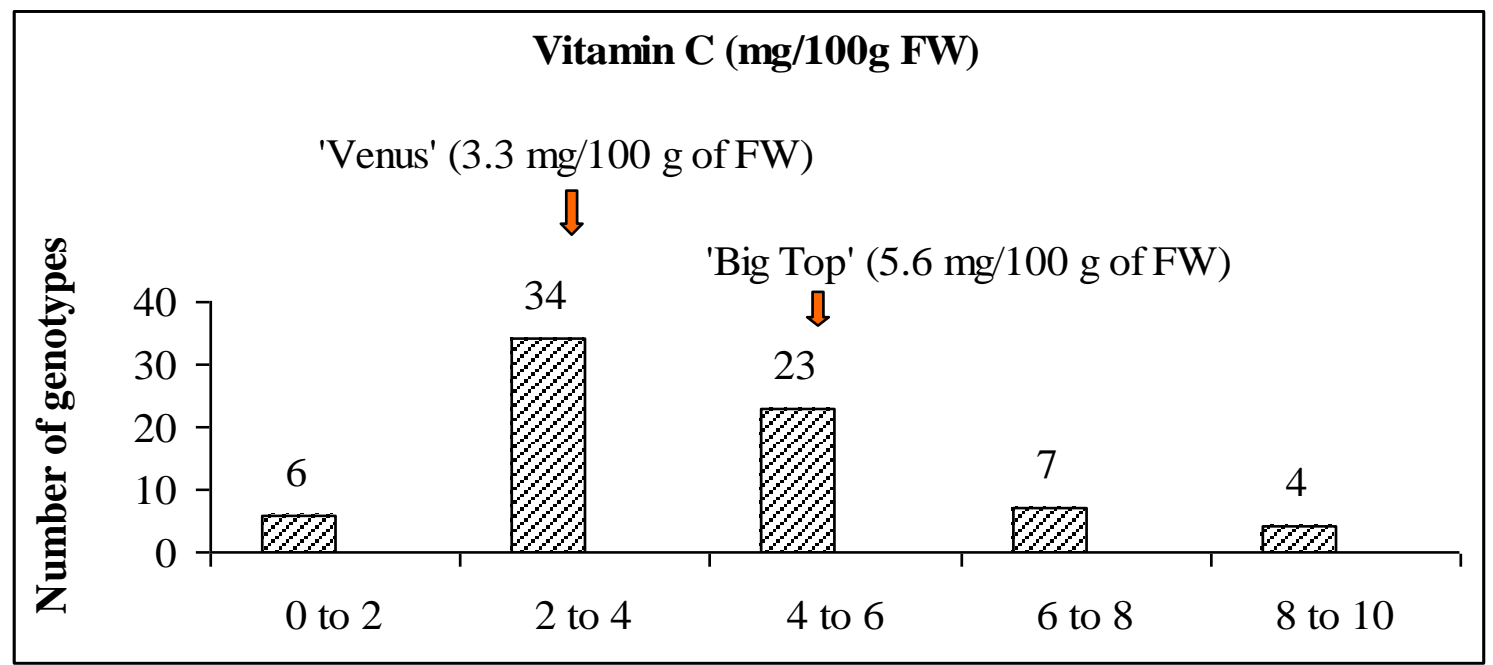

Fig. 1. Segregation of contents of vitamin $C$ in 'Venus' $x$ 'Big Top' progeny

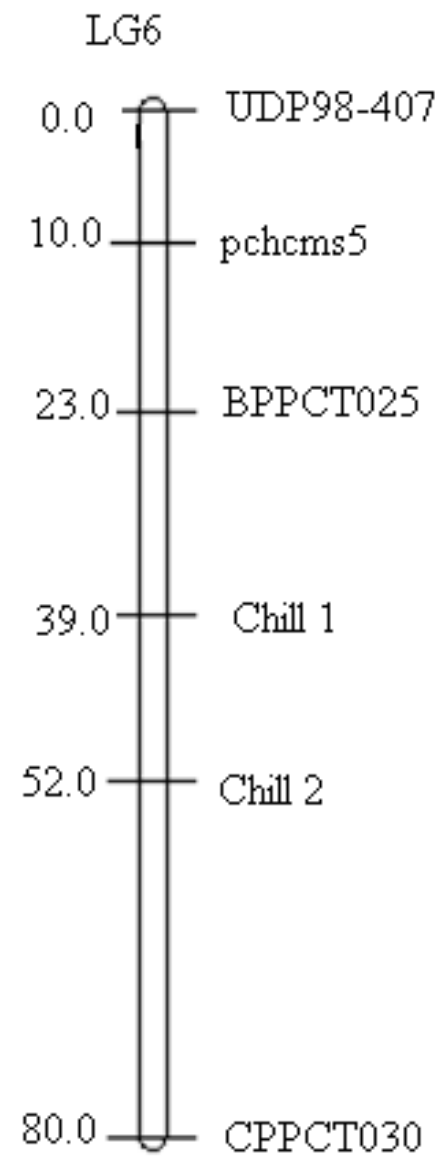

Fig. 2. Linkage map of peach chromosome 6 (LG 6) in the 'Venus' $x$ 'Big Top' progeny. 